\title{
Influence of weather and nitrogen fertilization on white clover percentage of permanent grassland
}

\author{
H. J. Kleter
}

Department of Field Crops and Grassland Husbandry, Agricultural University, Wageningen, The Netherlands

Received 16 October, 1967

\section{Summary}

The present paper includes a discussion of the variation in dry weight percentage of white clover in permanent grassland, based on investigations made over a number of years. Differences in clover percentage between experimental plots were observed. This percentage also varied from year to year and from month to month (Table 3 and 4, Fig. 1, 2 and 3). On the whole clover percentage in a given month clearly proved to be positively correlated with temperature and the global radiation in the previous month (Fig. 4 and 5, formula 2). The temperature in April also showed a distinct positive correlation with the mean clover percentage in the season (formula 1 and 2 ). Application of nitrogen proved to have an unfavourable influence on the clover percentage (formula 2), while no influence of precipitation and potential evaporation was observed.

\section{Introduction}

In the temperate zone, white clover forms a valuable component of fairly regularly grazed grassland; in most cases it is the only leguminous plant of mixed swards. The clover fraction of the sward is quite variable: significant differences occur between the grassland paddocks and within each paddock. There is much literature on clover content of the sward, on variation within one season (de Vries, 1940; Baker and Garwood, 1959; Weise, 1959) and on variation from year to year (Brenchley, 1935; Brockman and Wolton, 1963). As appears from numerous investigations, variation of clover percentage is associated with weather conditions. Literature on a positive influence of temperature up to $25^{\circ}$ or sometimes $30^{\circ} \mathrm{C}$ on clover growth and a favourable effect of light intensity agrees well in most cases (Mitchell, 1956; Brougham, 1959; Beinhart, 1963). However, there is much difference in opinion about the influence of water supply on the development of clover. On the one hand the clearly positive influence of irrigation is known (Robinson, Sprague and Leuck, 1952; van Burg, 1960), on the other both a favourable (de Vries, 1935; Weise, 1959) and an unfavourable influence of drought are reported in parts of the temperate zones without irrigation (Mulder, 1952; Kreil, Wacker and Kaltofen, 1961). Unfortunately this information does not indicate whether those responses are determined by drought or by the nature and growth of the competing grass species. In this case, only the clover percentage, so the grass/clover ratio was taken into consideration while the growth 
rate of white clover itself was not. The negative influence of fertilizer-nitrogen on the clover percentage is familiar enough ('t Hart, 1954; Linehan and Lowe, 1960).

The investigations under discussion included observations on the variation in the white clover percentage (dry weight) of the sward made in about 20 experimental plots of permanent grassland on sandy soil and on river clay near Wageningen from 1960 till 1966. Specific attention was paid to a number of climatic factors and to nitrogen application, which chiefly govern the fluctuations of the clover percentage in the seasons.

\section{Investigations and method}

In 196010 , and in the years 1961 till 196619 experimental plots of $100 \mathrm{~m}^{2}$ of permanent grassland were repeatedly sampled in the growing season according to the dry weight method. Half of the plots were on humus sandy soil and the rest on river clay. The number of samples per experimental plot per season ranged from 4 in 1965 to 18 in 1964 (Table 1). Each sample consisted of the material taken from 40 plots of $40 \mathrm{~cm}^{2}$. The resulting samples were composed of grass, white clover and other species. Then they were dried during 24 hours at $105^{\circ} \mathrm{C}$.

Table 1 Number of experimental plots and samples investigated

\begin{tabular}{lccc}
\hline Year & $\begin{array}{c}\text { Number } \\
\text { of plots }\end{array}$ & $\begin{array}{c}\text { Samples } \\
\text { min.-max. }\end{array}$ & $\begin{array}{c}\text { Number } \\
\text { of samples }\end{array}$ \\
1960 & 10 & $6-11$ & 84 \\
1961 & 19 & $9-12$ & 202 \\
1962 & 19 & $7-12$ & 171 \\
1963 & 19 & $9-12$ & 182 \\
1964 & 19 & $17-18$ & 332 \\
1965 & 19 & $4-4$ & 76 \\
Total & & & 1047 \\
\hline
\end{tabular}

In general two experimental plots were selected, viz. one with a white clover percentage which was high for the paddock of which it formed part and one with a percentage low for the paddock to which it belonged. The criterion for selection was that the clover regularly occurred in these plots. The plots on the humus sandy soil were hardly subject to lack of moisture, whereas those on river clay with a compact structure and a somewhat lower water-table $(40-180 \mathrm{~cm}$ below the grassland surface) were sometimes clearly affected by shortage of moisture in the summer months.

The potassium level (potassium rate 14-50), phosphate content (P-Al-value 10-137), magnesium $(65-360 / 10,000)$ and acidity $(\mathrm{pH}-\mathrm{KCl}$ 4.6-6.4) were sufficient for permanent grassland.

The annual quantity of effective pure nitrogen applied in the form of fertilizer and as a component of dung or liquid manure was on an average $113(0-173), 110(0-244)$, $115(0-219), 156(0-270)$ and $153(0-289) \mathrm{kg}$ per ha from 1961 to 1965 inclusive. Nitrogen application in 1960 was not exactly known, but the data available suggest, 


\begin{tabular}{|c|c|c|c|c|c|c|c|}
\hline & 1960 & 1961 & 1962 & 1963 & 1964 & 1965 & $\begin{array}{c}1930 \\
\text { till } \\
1961\end{array}$ \\
\hline \multicolumn{8}{|c|}{ Mean temperature during daytime in ${ }^{\circ} \mathrm{C}$} \\
\hline March up to June inclusive & 13.0 & 12.8 & 10.1 & 11.8 & 11.8 & 11.0 & 12.0 \\
\hline July up to October inclusive & 15.3 & 16.4 & 15.0 & 15.0 & 15.2 & 14.4 & 15.9 \\
\hline Mean growing season & 14.1 & 14.6 & 12.5 & 13.4 & 13.5 & 12.7 & 13.9 \\
\hline \multicolumn{8}{|c|}{ Light intensity in terms of cal.cm-2 day-1 } \\
\hline March up to June inclusive & 320 & 301 & 298 & 294 & 314 & 292 & 315 \\
\hline July up to October inclusive & 233 & 240 & 266 & 256 & 283 & 252 & 265 \\
\hline Mean growing season & 277 & 270 & 282 & 275 & 298 & 272 & 290 \\
\hline \multicolumn{8}{|c|}{ Precipitation minus potential evaporation expressed in $\mathrm{mm}$} \\
\hline March up to June inclusive & -140 & -2 & +12 & -16 & -76 & +88 & -54 \\
\hline July up to October inclusive & +311 & $+17 \overline{3}$ & +80 & +86 & +26 & +81 & +105 \\
\hline Growing season & +172 & +172 & +92 & +69 & -49 & +169 & +51 \\
\hline
\end{tabular}

that it approximated those of the years 1961, 1962 and 1963. In the period from 1960 to 1965 the botanical composition of the sward of the experimental plots investigated has once been fully studied following the method of dry weight analysis. As appeared from the results Lolium perenne (3-94\%), Poa trivialis (1-26\%) and Trifolium repens $(+-31 \%)$ proved to be the most common species. The fluctuation of white clover has mostly been studied in Lolium perenne and Poa trivialis turfs.

During the years of investigation the weather was rather variable (Table 2). Unlike in 1961, when the mean temperature during daytime (measured at 08.00, 14.00 and 19.00) was clearly above the long-term mean, it was below this average temperature in the growing season of 1962 and 1965. In the first half of the growing season of 1962 and 1965 it was colder than normally but the temperature was above normal in the years 1960 and 1961. With the exception of the 1964 growing season the amount of light received was not normal either. This remained so till the second half of the growing seasons; 1960 and 1964 are exceptions.

The moisture defined as precipitation minus potential evaporation (P-Ep) after Penman, (Kramer, 1957) was very variable of course. The 1960, 1961 and 1965 seasons were wetter than normally, whereas these in 1962 and 1963 were slightly dryer. The 1964 season was far dryer. It was also within the growing season, that considerable variation in moisture was observed. In the years 1962, 1963 and 1965 the first half of the growing season was wetter than normally, while the weather was dryer in the second half. However, the first part of 1960 was far dryer than normally the second period being far wetter. Furthermore the second half of the growing seasons of 1961 and 1964 could be referred to as wet and dry respectively.

\section{Results and discussion}

Influence of sampling date, experimental plot and sample standard error As has been mentioned in Table 1, in the years from 1960 to 1965, 971 herbage samples of permanent grassland were collected. The white clover percentage (dry 
weight) proved to be 5.2 on average, the two extremes per sample being 0.0 and 39.9 (Table 3). As appears from these values the total variation is quite considerable. Consequently the question arises how this variation is brought about. In order to know the answer, the data of 6 clay and 5 sandy experimental plots sampled between May and December from 1961 to 1964 inclusive, each time within a fortnight, were compiled and mathematically analysed by variance analysis (Table 4). The resulting year, month and experimental plot effects prove significant if $99 \%$ reliability is required. Moreover the year $\times$ month and year $\times$ experimental plot interactions are significant in the case of $99 \%$, those of month $\times$ experimental plot being significant if $95 \%$ applies. The standard deviation $(\sigma$ d.w. $\%$ ) of these 11 experimental plots is 5.71 , if the mean clover percentage is $6.2(<0.1-33.7)$. Variance analysis results into a deviation of 3.31. Thus it was possible to account for $66 \%$ of the total variance of the clover percentage.

One may wonder whether the residual variance is caused by an analysis and sample error or by other factors. Additional investigations were made in 1965 and 1967 aiming to gain some insight into the subject. Their results will be separately published and discussed later on. As appeared from them, the sample error was relatively higher with low than with high clover percentages. This error is approximately \pm 1 in samples of 40 gatherings in $100 \mathrm{~m}^{2}$ plots with a clover percentage of 6.2 . In this case i.e. when the percentage is 6.2 , the difference between the sample error and the residual variance 1 and 3.31 respectively shows, that the sample error has hardly any influence on the total variance. This is clearly demonstrated by the fact, that the error slightly reduces the residual standard deviation viz. from 3.31 to 3.15 only. This implies, that $30 \%$ of the clover percentage involved (6.2) remains inexplicable.

Table 3 White clover percentage (dry weight) of the sward

\begin{tabular}{lcr}
\hline Year & Mean & \multicolumn{1}{c}{ Extremes } \\
1960 & 5.7 & $0.0-22.7$ \\
1961 & 7.0 & $0.2-33.7$ \\
1962 & 3.9 & $<0.1-19.7$ \\
1963 & 6.3 & $<0.1-39.9$ \\
1964 & 3.9 & $0.0-17.6$ \\
Total & 5.2 & $0.0-39.9$ \\
\hline
\end{tabular}

Table 4 Final analysis (var, analysis white clover percentage; 11 experimental plots 1961 till 1965, May up to November inclusive)

\begin{tabular}{|c|c|c|c|c|c|}
\hline S.V. & $D . F$. & $S . S$. & $M . S$ & $F$-value & P.E.F ${ }^{y_{2}} y_{1}>F$ \\
\hline Years & 3 & 371.56 & 123.85 & 11.30 & 0.0000 \\
\hline Months & 6 & 1256.73 & 209.46 & 19.11 & 0.0000 \\
\hline Plots & 10 & 2532.65 & 253.27 & 23.10 & 0.0000 \\
\hline Year $\times$ month & 18 & 558.84 & 31.05 & 2.83 & 0.0002 \\
\hline Year $\times$ plot & 30 & 2398.69 & 79.96 & 7.29 & 0.0000 \\
\hline Month $\times$ plot & 60 & 931.62 & 15.53 & 1.42 & 0.0408 \\
\hline Residual (chance) & 180 & 1973.41 & 10.96 & - & - \\
\hline
\end{tabular}


The socalled residual variance is also caused by some variation in the area of the experimental plots. The same time is mattered how often and in what quantities the material was gathered. Moreover sampling date and the differences in the use of the experimental fields produced an effect. In some cases a sample came from a plot which had been mown or grazed beforehand whereas an one-month old herbage was found in another plot. Besides, the weather proved another factor of influence which will be dealt with in further detail.

It is useful to consider all data compiled from 1960 to 1964 inclusively to be able to study further the effects of variance analysis, which showed the same tendencies on both sandy soil and clay. Those data have been brought together as means of 19 experimental plots per month to be least effected by the heterogeneous use of the plots and the sample standard error. The 1960 data have been corrected by means of a regression calculation for level difference in percentage of clover which had to be carried out as the number of experimental plots was smaller than in the previous years. The resulting white clover percentages have been graphically represented in Figure 1. This figure clearly shows the differences in clover percentage between years and those between months. The yearly means calculated from this information have been included in Table 3. As appears from this table the yearly means vary to a certain extent which is otherwise in good agreement with existing literature. Brockman and Wolton (1963) e.g. found, that in 1961 considerably more clover occurred in British swards than in the next year. The values found suggest, that in the Netherlands years with much clover alternate with years of little clover, which reminds of the so-called biennial bearing. No clear correlation being found to exist between the clover percentage in the autumn and that of the next spring, it is nearer the mark to say, that the year differences in clover percentage have chiefly been the result of the weather conditions in the winter season. This will be further discussed in the following section.

On account of a smaller number of experimental plots and sampling dates in 1960 the yearly means included in Table 3 are not entirely comparable. Considering the average percentage of the samples taken in July-August 1960 to 1964 inclusively the percentages are 7, 9, 5, 9 and 6 . The tendency of these percentages and that of the yearly means of Figure 2 and Table 3 run parallel to a large extent.

The month differences in clover percentage which were the result of variance analy-

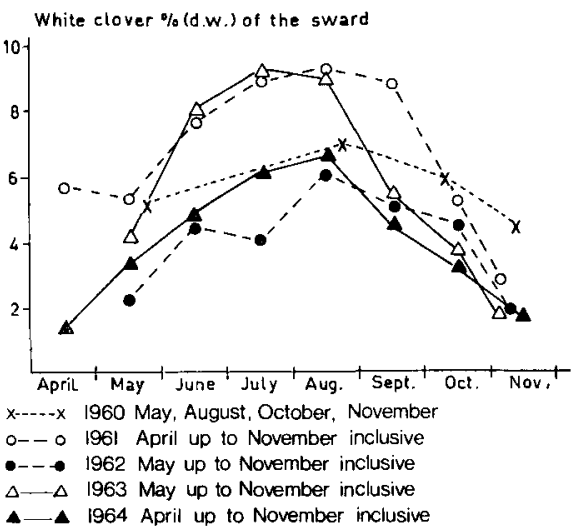

Fig. 1 Seasonal trend of the mean white clover percentage (dry weight) of the swards of $19 \mathrm{ex}$. perimental plots of $100 \mathrm{~m}^{2}$. 
sis stand out clearly in Figure 1. This percentage shows a considerable increase from spring to July-August and subsequently a constant decrease till it reaches a low value in autumn (Fig. 3). This development agrees well with the experiences and observations of Baker and Garwood (1959) and Weise (1959). The curves in Figure 1 are rather congruent for the various years. However, the marked decline from August to September 1963 is conspicuous, the more so, because that fall was far less significant in other years. This is related to the low temperature in August which will yet be dealt with.

As appears from the variance analysis, there is a significant difference in clover percentage between the experimental plots, the differences ranging from 2.5 to 11.7 .

The interactions found in Table 4 have been graphically represented in Figure 1, 2 and 3. Of course the interaction year $\times$ month derived from Figure 1 pertains to all data compiled in the year 1960, up to and including 1964. It is quite clear from this figure, that the growth pattern recurs annually, although the rise in one year is considerably sharper than in another. Figure 2 shows, that the year differences in terms of average values do not always occur in separate experimental plots. Over the years the clover percentage of the experimental plots with quite high values in the first year has so decreased, that the differences between the plots have become smaller. Figure 3 shows a similar picture for the month differences.

\section{Influence of weather conditions and nitrogen-fertilizer}

As was pointed out in the introduction not only nitrogen-fertilizer, but also the weather was a factor of influence on the grass/clover ratio. The monthly means of the clover percentage of 19 experimental plots have served as material on which the study of the influence in question could be based. Since no yearly means are taken into consideration, in this case it is justified to include the figures of 1965 when the data of only 2 months were compiled in the calculation work. At the same time the 1960 data were corrected for level difference as the number of experimental plots investigated was in that year smaller than from 1961 to 1966.

It was studied to what extent the clover percentage is related with temperature, light intensity, precipitation and precipitation minus potential evaporation of the month prior to that when sampling took place. No influence of precipitation and potential

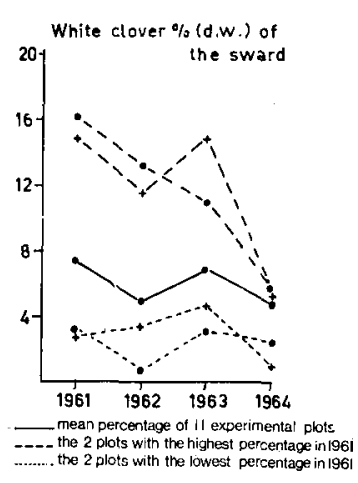

Fig. 2 Interaction of year and experimental plot on the white clover percentage of the sward.

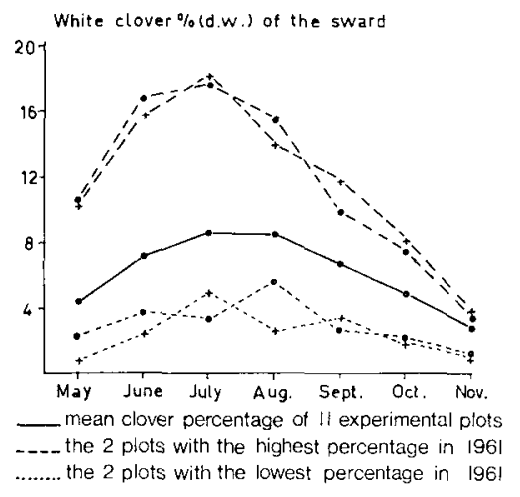

Fig. 3 Interaction of month and experimental plot on the white clover percentage of the sward. 
evaporation could be shown in the years of investigation, although it is justified to refer to the 1964 and 1965 seasons as dry and extremely wet respectively, the 1960, 1962 and 1963 growing seasons inclusively ranging from fairly dry to quite wet. Figure 4 and 5 illustrate the relation with temperature and with light intensity of the preceding month. A clear connection proves to exist between clover percentage/ temperature on the one hand and the global radiation on the other. The spread of the separate points is wide as compared with the regression lines, but the pertaining correlation coefficients, 0.63 and 0.64 , are significant at $99 \%$. The regressions of the separate months practically always depart from the average regressions and sometimes even to a great extent. However, only in May the regression for clover content in respect to the temperature of the preceding month (April) is significant at $95 \%$, with a correlation coefficient of 0.86 . Furthermore it should be noted, that attempts failed to show, that mathematically the regressions for the separate months did not differ reliably from the average regressions (Calc. $-\mathrm{F} /$ Theor. $-\mathrm{F}=0.68$ and 0.60 at $95 \%$ and $90 \%$ respectively) in spite of the fact, that the multiple regression analysis was carried out, temperature and light intensity being introduced as explanatory variables. Therefore it is justified to calculate average regressions from these data while those results can be looked upon as a whole.

The year differences in clover percentage found in Figure 1 prove to persist in the Figures 4 and 5 . However, this has not been given to avoid a troublesome diversity of signs although this caused part of the spread.

It is familiar enough, that the influence of low temperatures on a snowy turf may be quite different from that on an open or a marshy sward. This winter influence has not been further studied here. Considering the influence of temperature and light intensity on white clover it is justified to assume, that the weather conditions of the winter months have influenced the year differences found. It is supposed, that the

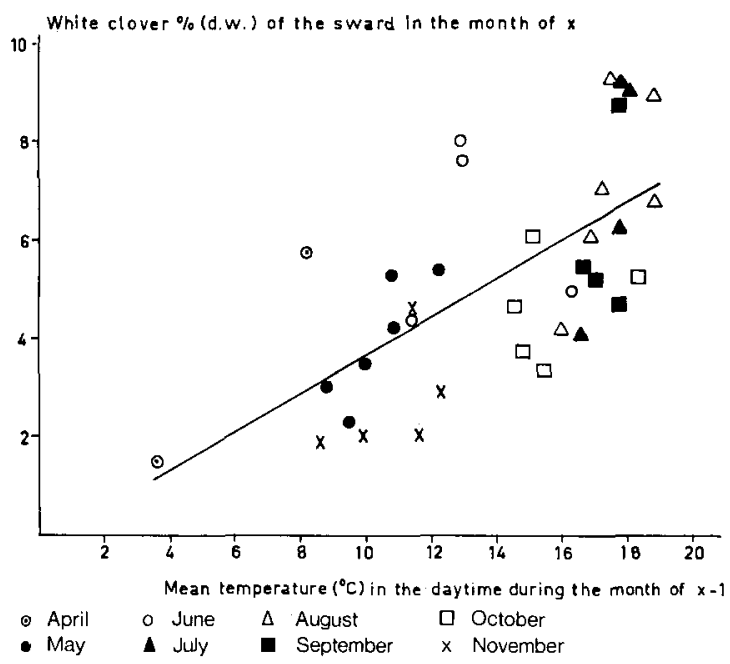

Fig. 4 Relation between the monthly means of the white clover percentage of the sward of 19 experimental plots $(x)$ and the mean temperature during daytime in ${ }^{\circ} \mathrm{C}$ in the month preceding that of sampling $(x-1)$. 
Fig. 5 Connection between the monthly means of the white clover percentage of the sward of 19 experimental plots $(x)$ and the light intensity in cal.cm-2.day-1 in the month preceding that of sampling $(x-I)$.

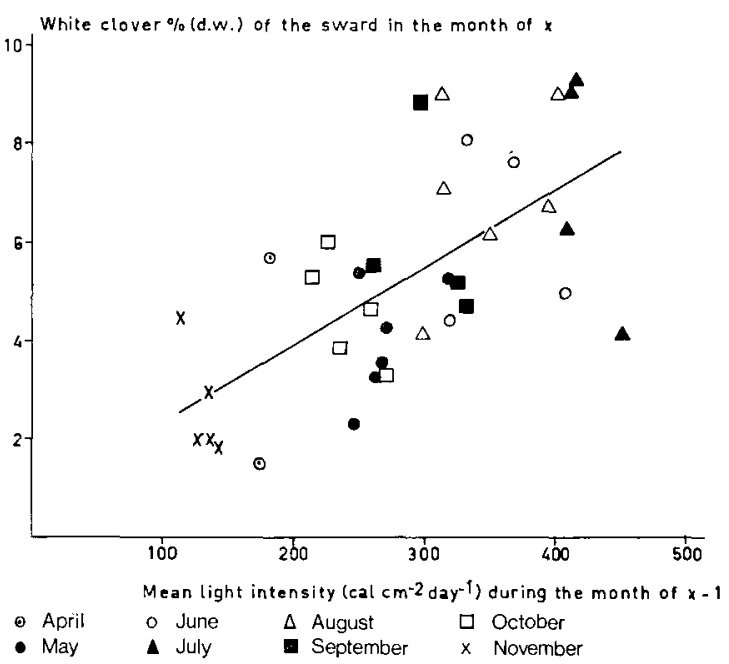

clover percentage in May may be considered to be the resultant of the winter influence. As regards the clover percentages found from May 1960 till 1965 inclusively, April temperature accounted for $73 \%$ of the variance, light intensity and temperature in April explaining 93\%. The regression resulting from this calculation is expressed in the following equation:

$\mathrm{y}=0.827 \mathrm{x}_{\mathrm{l}}+0.0208 \mathrm{x}_{\mathbf{2}}-10.16\left(\mathrm{R}^{2}=0.93\right)$

in which: $\mathrm{y}=$ white clover percentage (dry weight) of the sward in May; $\mathrm{x}_{1}=$ mean temperature during daytime expressed in ${ }^{\circ} \mathrm{C}$ in April; and $\mathrm{x}_{2}=$ mean light intensity in terms of cal.cm-2. day-1 in April.

As appears from this, especially the temperature early in the spring season of those years was a factor governing the clover percentage in May and the year differences found in spring and summer as shown in Figure 1 and 2. No important wintering-out of grasses was observed in the years in question. The positive correlation with the temperature means that at temperatures common in April clover growth is considerably more influenced by a rise in temperature than the competing grasses Lolium perenne and Poa trivialis. This fully agrees with data cited in the literature. The same applies to the positive correlation with the light intensity, since it is a common experience that white clover is susceptible to lack of light. It may well be assumed, that in the case of a slow rise of temperature early in the spring the grass will improve its chances of competing with clover. But if the temperature should suddenly reach a fairly high value in that period, the growth of white clover can start at the same time as that of grass, which results into higher clover percentages. The light intensity is an important factor promoting the development of stolons which begin to form leaves under the influence of rising temperature (Beinhart, 1963).

It is also interesting to find out to what extent light and temperature vary when 
independent. It is studied how far these factors are related to each other in order to gain an insight into that question. During the months of investigation $35 \%$ of the temperature variance was explained by the light intensity which indeed suggests no onerous connection. Then an attempt was made to find for all monthly means of the clover percentage how far it was possible to account for the variation by the way of multiple regression calculation. Such explaining variables as temperature and light intensity of the month preceding that of sampling, and temperature and light in April as well as the annual amount of nitrogen fertilizer applied were introduced to serve that purpose. The following equation is the result of this regression calculation:

$y=0.137 x_{1}+0.0140 x_{2}+0.970 x_{3}+0.0141 x_{4}-0.0149 x_{5}-12.74\left(R^{2}=0.80\right)$

in which: $\mathrm{y}=$ white clover percentage (dry weight) of the sward in a certain month of the growing season; $\mathrm{x}_{1}=$ mean temperature during daytime in ${ }^{\circ} \mathrm{C}$ in the month preceding the month of sampling; $\mathrm{x}_{2}=$ mean light intensity in $\mathrm{cal} \mathrm{cm}^{-2}$. day-1 in the month preceding the month of sampling; $x_{3}=$ mean temperature during daytime in ${ }^{\circ} \mathrm{C}$ in April $\mathrm{x}_{4}=$ mean light intensity in cal.cm-2. day-1 in April; and $\mathrm{x}_{5}=$ annual amount of nitrogen fertilizer applied in $\mathrm{kg} \mathrm{N}$ per ha.

This regression calculation shows, that $80 \%$ of the variance in clover percentage could be explained by the introduced factors. It is remarkable, that a rise of the spring temperature $\left(\mathrm{x}_{3}\right)$ by $1{ }^{\circ} \mathrm{C}$ would result in an increase of clover percentage by approximately 1 , whereas a similar rise of the temperature in the rest of the months $\left(\mathrm{x}_{1}\right)$ increases this percentage by only 0.14 . Obviously a slight difference in temperature is of vital importance for the competitive ratio between white clover and grasses as long as the mean temperature during daytime remains below $10^{\circ} \mathrm{C}$. If the temperature considerably surpasses this value the influence is markedly less great. However, the influence of light intensity in April $\left(\mathrm{x}_{4}\right)$ and that of the other months $\left(\mathrm{x}_{2}\right)$ is practically the same.

The mean decrease of clover percentage was 1.49 when the annual application of nitrogen increased by $100 \mathrm{~kg} \mathrm{~N}$ per ha, i.e. less than is reported in literature. For 't Hart (1954) observed in experiments made over several years with annual fertilizer application of $40-80$ and $160-200 \mathrm{~kg} \mathrm{~N}$ per ha, that the mean clover percentage of the sward was 6 and 2 in summer. This leads to the conclusion, that an increase of annual nitrogen fertilization of $100 \mathrm{~kg} \mathrm{~N}$ per ha is connected with a decrease of clover percentage of 3.3. However the results of further investigation indicated, that the negative nitrogen effect is greater in the summer season than in spring or autumn. This was quite clear, if the theoretical clover percentage was calculated for 1964 and 1965 by means of a regression equation for the data of 1960 up to 1963 inclusive. Comparing with 1960 up to 1963 inclusive, when it hardly differed and it had not been introduced as an explaining variable, the application of nitrogen fertilizer had been increased by about $40 \mathrm{~kg} \mathrm{~N}$ per ha in 1964 and in the next year. The thus calculated clover percentage was only slightly higher in spring and in autumn, but in August it was more than $1 \%$ higher than had been analysed. This shows, that for the nitrogen level in question an increase of the annual application by $100 \mathrm{~kg} \mathrm{~N}$ per ha resulted into a decrease of over $2.5 \%$ clover. This decrease of $2.5 \%$ is considerably more than the mean $1.5 \%$ but less than the $3.3 \%$ found by 't Hart. In general nitrogen proves to produce a rather strong negative effect on the clover percentage in the sward. This is most clearly observed in summer because on the one hand the clover percentage reaches its highest value at that time and on the other, because 
then the nitrogen has been able to make its influence felt. Making allowance for the varying negative effect of nitrogen fertilizer it is justified to state, that with the aid of the calculated regression equations it will be possible to make a satisfactory estimate of the white clover percentage of the sward to be expected in permanent grassland. Needless to observe, that it is recommendable to allow for possible season and year differences in clover percentage when mapping grassland vegetation.

\section{Acknowledgements}

The author wishes to thank Mrs. Ir. J. A. Bakhuis for her conduct of the investigation described and her stimulating influence on the worked involved, and $\mathrm{Mr}$. G. Franken for the translation of the manuscript of this paper.

\section{References}

Baker, H. J. and Garwood, E. A., 1959. Studies on the root development of herbage plants. J. Br. Grassl. Soc., 12: 94-104.

Beinhart, G., 1963. Effects of environment on meristematic development, leaf area, and growth of white clover. Crop. Sci., 3 : 209-213.

Brenchley, W. E., 1935. The influence of season and of the application of lime on the botanical composition of grassland herbage. Ann. App. Biol., 22, 2 : 183-207.

Brockman, J. S. and Wolton, K. M., 1963. The use of nitrogen on grass/white clover swards. J. Br. Grassl. Soc., 18, 1: 7-13.

Brougham, R. W., 1959. The effects of season and weather on the growth rate of a ryegrass and clover pasture. N.Z. J. Agr. Res., 2 : 283-296.

Burg, P. F. J. van, 1960. Nitrogen fertilization and the seasonal production of grassland herbage Proc. 8th Int. Grassl. Congr., 5A/5 : 142-146.

Hart, M. L. 't, 1954. De invloed van stikstofbemesting op de botanische samenstelling van grasland. Stikstof, $1: 4-10$.

Kramer, C., 1957. Berekening van de gemiddelde grootte van de verdamping voor de verschillende delen van Nederland volgens de methode Penman. K.N.M.I. Med. en Verh., 70.

Kreil, W., Wacker, G. and Kaltofen, H., 1961. Dreijährige Versuchsergebnisse über die Düngung einer Weide mit verschieden hohen N-Gaben (1958-1960). Landeskultur, 3 : 225-257.

Linehan, P. A. and Lowe, J., 1960. Yielding capacity and grass/clover ratio of herbage swards as influenced by fertilizer treatments. Proc. 8th Int. Grassl. Congr., 5A/3: 133-137.

Mitchell, K. J., 1956. The influence of light and temperature on the growth of pasture species. Proc. 7th Int. Grassl. Congr., 4, 1 : 58-69.

Mulder, E. G., 1952. Fertilizer vs. legume nitrogen for grasslands. Proc. 6th Int. Grassl. Congr., $740-748$

Robinson, R. R., Sprague, V. G. and Lueck, A. G., 1952. The effect of clipping, nitrogen fertilization and clipping treatments on persistence of clover and on total and seasonal distribution of yields in a Kentucky bluegrass sod. Agron. J., $44: 239-244$.

Vries, D. M. de, 1935. De nadelige invloed van droogte op grasland. Meded. v.h. Rijkslandb. proefst. te Groningen, 46.

Vries, D. M. de, 1940. Verslag van een vergelijkend onderzoek van een drietal methoden van botanisch graslandonderzoek, in verband met de grootte der seizoensverschillen in samenstelling der graszode. Versl. Landb. Onderz., 46/6A : 313-341.

Weise, F., 1959. Die Bedeutung des Weissklees auf Intensivweiden. Das Grünland, 12 : 78-79. 